\title{
Incorporation of Amino Acid into Protein by Utilizing a Cell-Free System from Paramecium
}

\author{
By A. H. REISNER AND HELEN MACINDOE \\ C.S.I.R.O., Division of Animal Genetics, Delhi Road, North Ryde, N.S.W., \\ Australia
}

(Accepted for publication 14 October 1966)

\begin{abstract}
SUMMARY
Cell-free incorporation of amino acid into paramecium protein was accomplished by using ribosomes, soluble fraction, guanosine triphosphate and adenosine triphosphate. Less than $20 \%$ of the incorporated label was detected in the soluble fraction, indicating that little if any complete de novo synthesis occurred. Incorporation was markedly decreased by submicrogram concentrations of RNase and by decreasing $\left[\mathrm{Mg}^{2+}\right]$ to below $3 \mu$ moles/ ml. A 'pH 5 fraction' from mouse liver was able to replace the paramecium soluble fraction but attempts to obtain active ' $\mathrm{pH} 5$ fractions' from paramecium failed. Evidence is presented for the presence of polyribosomes in paramecium; there was some indication that they were active in amino acid incorporation. Following incorporation, 80s ribosomes labelled with amino acid were recovered; subjecting these to $\mathrm{Mg}^{2+}$-deficient buffer caused dissociation into $45 \mathrm{~s}$ and $30 \mathrm{~s}$ units. A considerable portion of the label remained with the heavier unit.
\end{abstract}

\section{INTRODUCTION}

Fruton (1963) and Campbell (1965) have recently reviewed the considerable research done in recent years on cell-free incorporation of amino acid into protein ('protein synthesis'). However, while extensive studies have been undertaken with bacterial and mammalian systems and to a lesser extent with extracts from fungal and higher plant tissue, work on the protozoa is almost non-existent. The literature contains three papers on Tetrahymena pyriformis (Mager \& Lipmann, 1958; Mager, 1960; Seaman, 1962), and one on the trypanosome Crithidia oncopelti (Chesters, 1966). With respect to ribosomally-controlled protein synthesis only the studies of Mager \& Lipmann and of Chesters are relevant. The present paper deals with amino acid incorporation into protein in a cell-free system obtained from the ciliated protozoan Paramecium aurelia. Because paramecium is genetically the most extensively studied protozoan, it seemed advisable to determine whether or not its protein synthesis fell into the 'classical' pattern.

\section{METHODS}

Adenosine triphosphate (ATP), guanosine triphosphate (GTP), creatine phosphate, creatine phosphokinase, pronase and ${ }^{14} \mathrm{C}$-labelled amino acids were purchased from Calbiochem, Los Angeles, U.S.A. Reconstituted ${ }^{14} \mathrm{C}$-protein hydrolysate (lot 6601) was obtained from Schwarz Bioresearch, Orangeburg, New York. Deoxyribonuclease (DNase) and ribonuclease (RNase) were obtained from Sigma Chemical Company, St Louis, Mo. Proteose peptone, yeast extract, Sabouraud dextrose broth and fluid Vol. 46, No. 3, was issued April 1967 
thioglycollate medium were obtained from Difco Laboratories, Detroit, Michigan, Vegemite from Kraft Foods Ltd., Melbourne, Australia, and compressed bakers' yeast from the Yeast Company of Australia Pty. Ltd., Sydney. Lactalbumin hydrolysate (enzymic) was obtained from Nutritional Biochemicals Corporation, Cleveland, Ohio, as was puromycin dihydrochloride. Streptomycin sulphate was obtained from Evans Medical (Pty.) Ltd., and chloramphenicol from Parke Davis and Co. Ltd., Sydney.

Organism. Paramecium aurelia stock 51 (syngen 4) free of $\kappa$ and expressing serotypic antigen $51 \mathrm{~A}$ was used throughout the work. A culture of sterile organisms was kindly supplied to us by Dr W. J. van Wagtendonk and has now been maintained in our laboratory for 3 years.

Culture medium. Cultures were grown at $25^{\circ}$ in a medium consisting of $0.25 \%$ $(\mathrm{w} / \mathrm{v})$ Vegemite, $0.2 \%(\mathrm{w} / \mathrm{v})$ yeast extract, $0.75 \%(\mathrm{w} / \mathrm{v})$ proteose peptone and $23 \%(\mathrm{v} / \mathrm{v})$ dialysed yeast supernatant (see below). This medium was autoclaved as one mixture at $17 \mathrm{lb}$./sq.in. (about $123^{\circ}$ ) for $40 \mathrm{~min}$. Growth rate was one fission/day and peak population equalled $4 \times 10^{3}$ organisms $/ \mathrm{ml}$.

Preparation of dialysed yeast supernatant fluid. To every $1000 \mathrm{ml}$. water was added $3.6 \mathrm{~kg}$. of grated live compressed baker's yeast. The slurry was autoclaved for $45 \mathrm{~min}$. at $10 \mathrm{lb}$./sq.in., cooled to room temperature and then centrifuged at $3000 \mathrm{~g}$ for $15 \mathrm{~min}$. The autolysate supernatant fluid was decanted into dialysis tubing and the tubing sealed air-free but with about $20 \%$ excess potential volume to preclude bursting. After autoclaving for 30 min., the material was dialysed for $60 \mathrm{hr}$ against running tap water. The dialysis residue, when not used immediately, was either stored at $2^{\circ}$ in the dialysis bags, or frozen and stored at $-20^{\circ}$. It contained about $2 \%(\mathrm{w} / \mathrm{v})$ solids.

Tests for sterility. All stock tubes of paramecia were routinely tested for bacterial sterility at the time of subculturing (once each week) by using Sabouraud dextrose broth, fluid thioglycollate medium and a yeast extract + lactalbumin hydrolysate medium $(0.5 \%$ yeast extract, $0.5 \%$ lactalbumin hydrolysate, $0.05 \%$ glucose; $\mathrm{w} / \mathrm{v})$ and tests were observed for 7 days. From time to time sterility tests were held for 21-28 days as a further check on contamination by slow growing bacteria and fungi. Absence of observable growth in these tests was taken to mean that we were dealing with a singlemembered (axenic) culture of paramecia.

Bacterial counts of experimental fractions were made by plating on $2 \%$ agar plates containing $0.5 \%(\mathrm{w} / \mathrm{v})$ each of yeast extract, lactalbumin hydrolysate and glucose. Samples were also taken from each flask of a mass culture for testing in the three liquid media.

Preparation of cell fractions (all steps at $0-4^{\circ}$ ). Mass cultures of paramecia were harvested as previously described (Macindoe \& Reisner, 1967). Following packing of the organisms at $3000 \mathrm{~g}$ the dark top layer of deposit was aspirated off. The organisms, after being resuspended in medium A (250 mM-sucrose, $50 \mathrm{~mm}$-tris, $25 \mathrm{mM}-\mathrm{KCl}$, $5 \mathrm{mM}^{-} \mathrm{MgCl}_{2}, \mathrm{pH} \mathrm{7.6)}$ at 5 to $7 \times 10^{6}$ organisms $/ \mathrm{ml}$., were homogenized manually in a glass and Teflon grinder. Less than $1 \%$ of whole paramecia were detected following this homogenization. The homogenate was centrifuged at $3000 \mathrm{~g}$ for $15 \mathrm{~min}$. and the supernatant fluid decanted and centrifuged at $10,000 \mathrm{~g}$ for $15 \mathrm{~min}$. This supernatant fluid was used for incorporation experiments not requiring additional fractionation. To separate ribosomes from the cell sap a $10,000 \mathrm{~g}$ supernatant fluid was centrifuged for $40 \mathrm{~min}$. at $150,000 \mathrm{~g}$. The top two-thirds of this supernatant fluid was removed for experimental use, the bottom third discarded, and after surface rinsing the pellet was resuspended in medium $A$. 
Fractionation of mouse liver (all steps at $0-4^{\circ}$ ). Livers from freshly killed random bred mice were excised into cold medium $\mathrm{A}$ and minced. Additional medium $\mathrm{A}$ was added to give $2.5 \mathrm{ml}$. medium $\mathrm{A} / \mathrm{g}$. wet weight liver. The material was then processed as described in the previous section except that the $10,000 \mathrm{~g}$ centrifugation was replaced by one at $12,500 \mathrm{~g}$.

Preparation of ' $\mathrm{pH} 5$ fraction'. Freshly prepared $150,000 \mathrm{~g}$ supernatant fluid from mouse liver was diluted threefold with medium $A$ and placed in ice. With constant stirring it was adjusted to $\mathrm{pH} 5 \cdot 2$ by the dropwise addition of cold $0 \cdot 1 \mathrm{~N}$-acetic acid and then centrifuged for $15 \mathrm{~min}$. at $3000 \mathrm{~g}$. After discarding the supernatant fluid the pellet was surface-rinsed with medium $A$ and then resuspended in medium $A$ and centrifuged again at $3000 \mathrm{~g}$ for $15 \mathrm{~min}$.; the supernatant was then decanted and held in ice until used.

Repeated attempts to obtain an active ' $\mathrm{pH} 5$ fraction' from paramecia have failed.

Preparation of ${ }^{14} \mathrm{C}$-amino acid-labelled 80 s ribosomes. To prepare $80 \mathrm{~s}$ ribosomes labelled with a single ${ }^{14} \mathrm{C}$-amino acid the $150,000 \mathrm{~g}$ pellet fraction from paramecia was obtained as described above. After resuspension in medium A from which sucrose was omitted it was mixed with 'pH 5 fraction' from mouse liver. The incubation conditions are given in Fig. $6 a$. Preparation of 80 s ribosomes labelled with ${ }^{14} \mathrm{C}$-reconstituted protein hydrolysate was done by using paramecium $10,000 \mathrm{~g}$ supernatant fluid. Following incubation both types of preparation were layered on 15-30\% linear sucrose gradients in medium A and centrifuged for $3 \mathrm{hr}$ at 53,000 $\mathrm{g}$ in a Spinco SW 25-1 rotor. Samples $\left(1 \mathrm{ml}\right.$.) were collected through the bottom of the tubes, the $E_{260}$ value determined and the samples containing the 80s particles pooled.

Chemical estimations. Protein was estimated by the method of Lowry, Rosebrough, Farr \& Randall (1951). $\mathrm{Mg}^{2+}$ was estimated by the Orange \& Rhein (1951) method.

Radioactive counting. TCA insoluble material. Samples for counting were suspended in $5 \%(\mathrm{w} / \mathrm{v}) \mathrm{TCA}$, heated $20 \mathrm{~min}$. at $90^{\circ}$, chilled in ice and then centrifuged. The pellet was dissolved in $0.5 \mathrm{~N}-\mathrm{NaOH}$ and then re-precipitated by adding two volumes of $10 \%$ (w/v) TCA solution and centrifuged. The pellet was then resuspended and centrifuged first in water, then in ethanol and finally in ether. The ether-washed pellet was dissolved in $0.5 \mathrm{ml}$. Hyamine- $10 \mathrm{x}$ to which was added $10 \mathrm{ml}$. scintillator $(0.5 \%, \mathrm{w} / \mathrm{v}, 2,5$-diphenyloxazole (PPO) and $0.03 \% \mathrm{w} / \mathrm{v}$, 1,4-bis-2-(4-methyl-5-phenyloxazolyl)-benzene(dimethyl POPOP) in toluene).

TCA soluble material. One $\mathrm{ml}$. of aqueous sample $(5 \%, \mathrm{w} / \mathrm{v}, \mathrm{TCA})$ was added to $10 \mathrm{ml}$. of scintillation fluid (as above but with $2 \%(\mathrm{v} / \mathrm{v})$ Triton X-100 added). $0 \cdot 6 \mathrm{~g}$. of Cab-O-Sil (Godfrey L. Cabot. Inc., U.S.A.) was then added to the vial and the mixture shaken vigorously.

Counting was performed in an automatic liquid scintillation counter. Counting efficiency for ${ }^{14} \mathrm{C}$ based on internal standardization was $85 \pm 2 \%$ for all TCA insoluble samples and $67 \pm 1 \%$ for TCA-soluble samples.

Pronase-treated subfractions from paramecium 10,000 g supernatant fluid. A paramecium $10,000 \mathrm{~g}$ supernatant fluid was obtained and incubated as described in Table 3 . Following incubation $9.8 \mathrm{ml}$. of the mixture (equiv. $49 \mathrm{mg}$. protein) was chilled to $0^{\circ}$ and then centrifuged for $90 \mathrm{~min}$. at $150,000 \mathrm{~g}$. The top $6.5 \mathrm{ml}$. of this $150,000 \mathrm{~g}$ supernatant fluid were removed, mixed with an equal volume of saturated $\left(\mathrm{NH}_{4}\right)_{2} \mathrm{SO}_{4}$ solution and centrifuged for $20 \mathrm{~min}$. at $14,000 \mathrm{~g}$. The pellet was dissolved in $2.5 \mathrm{ml}$. medium A (lacking sucrose) and dialysed overnight against two 11 . changes of 
medium. The remaining $150,000 \mathrm{~g}$ supernatant fluid was discarded and the pellet surface-rinsed with medium A. After resuspending it in $2.5 \mathrm{ml}$. medium A (no sucrose) it was dialysed overnight against two 11 . changes of the medium.

Following dialysis $0.2 \mathrm{mg}$. pronase was added to $1 \mathrm{ml}$. samples of the fractions which were then incubated for $45 \mathrm{~min}$. at $37^{\circ}$, together with their controls. After adding $1 \mathrm{ml}$. of $10 \%(\mathrm{w} / \mathrm{v}) \mathrm{TCA}$ the mixtures were centrifuged at $3000 \mathrm{~g}$ and $1 \mathrm{ml}$. of each supernatant fluid was removed for counting. The remaining supernatant fluid was discarded and the TCA-precipitate worked up for counting.

\title{
RESULTS
}

Table 1 shows that the components of the $10,000 \mathrm{~g}$ supernatant fluid were capable of incorporating amino acid. Both the $150,000 \mathrm{~g}$ pellet and the $150,000 \mathrm{~g}$ supernatant fluid were necessary as well as ATP, GTP, creatine phosphate and creatine phosphokinase (AGCC) as a group. In the complete system 1240 C.P.M./mg. pellet-protein were incorporated, the equivalent of $6.7 \times 10^{-5} \mu$ mole valine. Comparable results were obtained in experiments with L-alanine-1-14 $\mathrm{C}$ and L-leucine-1 $1{ }^{14} \mathrm{C}$.

\section{Table 1. Incorporation of $L$-valine-1 ${ }^{14} C$ into the components of paramecium $10,000 \mathrm{~g}$ supernatant fluid fraction}

\begin{abstract}
The $10,000 \mathrm{~g}$ supernatant fluid was centrifuged $40 \mathrm{~min}$, at $150,000 \mathrm{~g}$. Experimental conditions: volume $=1.7 \mathrm{ml}$. Label, L-valine-1 $-^{14} \mathrm{C} 0.25 \mu \mathrm{c}$. (specific activity, $9.8 \mu \mathrm{c} . / \mu \mathrm{mole}$ ). AGCC $=$ ATP, $5 \mu$ moles; GTP, $0.5 \mu$ mole; creatine phosphate, $30 \mu$ moles; creatine phosphokinase, $100 \mu \mathrm{g}$. $150,000 \mathrm{~g}$ pellet, $190 \mu \mathrm{g}$. protein; $150,000 \mathrm{~g}$ supernatant fluid, $600 \mu \mathrm{g}$. protein. Sucrose, $300 \mu$ moles; tris, $60 \mu$ moles; $\mathrm{KCl}, 30 \mu$ moles; $\mathrm{MgCl}_{2}, 6 \mu$ moles, $\mathrm{pH} 7 \cdot 6$. Incubated $45 \mathrm{~min}$. at $33^{\circ}$, reaction stopped with addition of $2 \mathrm{ml}$. cold medium A containing $5 \mathrm{mg}$. bovine gamma globulin and $5 \mathrm{mg}$. of ${ }^{12} \mathrm{C}-\mathrm{DL}$-valine followed by $4 \mathrm{ml} .10 \%$ (w/v) TCA.
\end{abstract}

$\begin{array}{lcc} & \overbrace{\text { +AGCC }} & \text { - AGCC } \\ 150,000 \mathrm{~g} \text { pellet }+150,000 \mathrm{~g} \text { supernatant } & 235 & 5 \\ 150,000 \mathrm{~g} \text { pellet } & 20 & 8 \\ 150,000 \mathrm{~g} \text { supernatant } & 5 & 6\end{array}$

\section{The effect of various additives on incorporation of amino acid} into a $10,000 \mathrm{~g}$ supernatant fluid

The response of a paramecium $10,000 \mathrm{~g}$ supernatant fluid to ATP, GTP, creatine phosphate and creatine phosphokinase in all admixtures is depicted in Fig. 1, as well as the effect of deoxyribonuclease and ribonuclease when added just before incubation. It is apparent that the DNase had little effect on incorporation (90 C.P.M. vs. 108) while RNase at a final concentration of $0.6 \mu \mathrm{g}$. $/ \mathrm{ml}$. caused a marked depression of incorporation (31 C.P.M. vs. 108). Both GTP and ATP (or the ATP generating system) were required for maximum incorporation, but the ATP preparation also exerted inhibition. For example, when added to the other three co-factors, it caused a $40 \%$ decrease in incorporation.

The dependence of amino acid incorporation by the $10,000 \mathrm{~g}$ supernatant fluid on $\left[\mathrm{Mg}^{2+}\right]$ is shown in Fig. 2. The concentration of $\mathrm{Mg}^{2+}$ was critical; maximum incorporation occurred at about $5 \mu \mathrm{moles} / \mathrm{ml}$. 


\section{Incorporation of amino acid into the $10,000 \mathrm{~g}$ supernatant versus time}

A time-course study of incorporation into a paramecium $10,000 \mathrm{~g}$ supernatant fluid is shown in Fig. 3. Linear incorporation lasted less than $5 \mathrm{~min}$. and no significant incorporation occurred after $10 \mathrm{~min}$. The fact that no loss of TCA-insoluble label occurred up to $60 \mathrm{~min}$. of incubation indicated that proteolytic activity was not significant under the incubation conditions used.

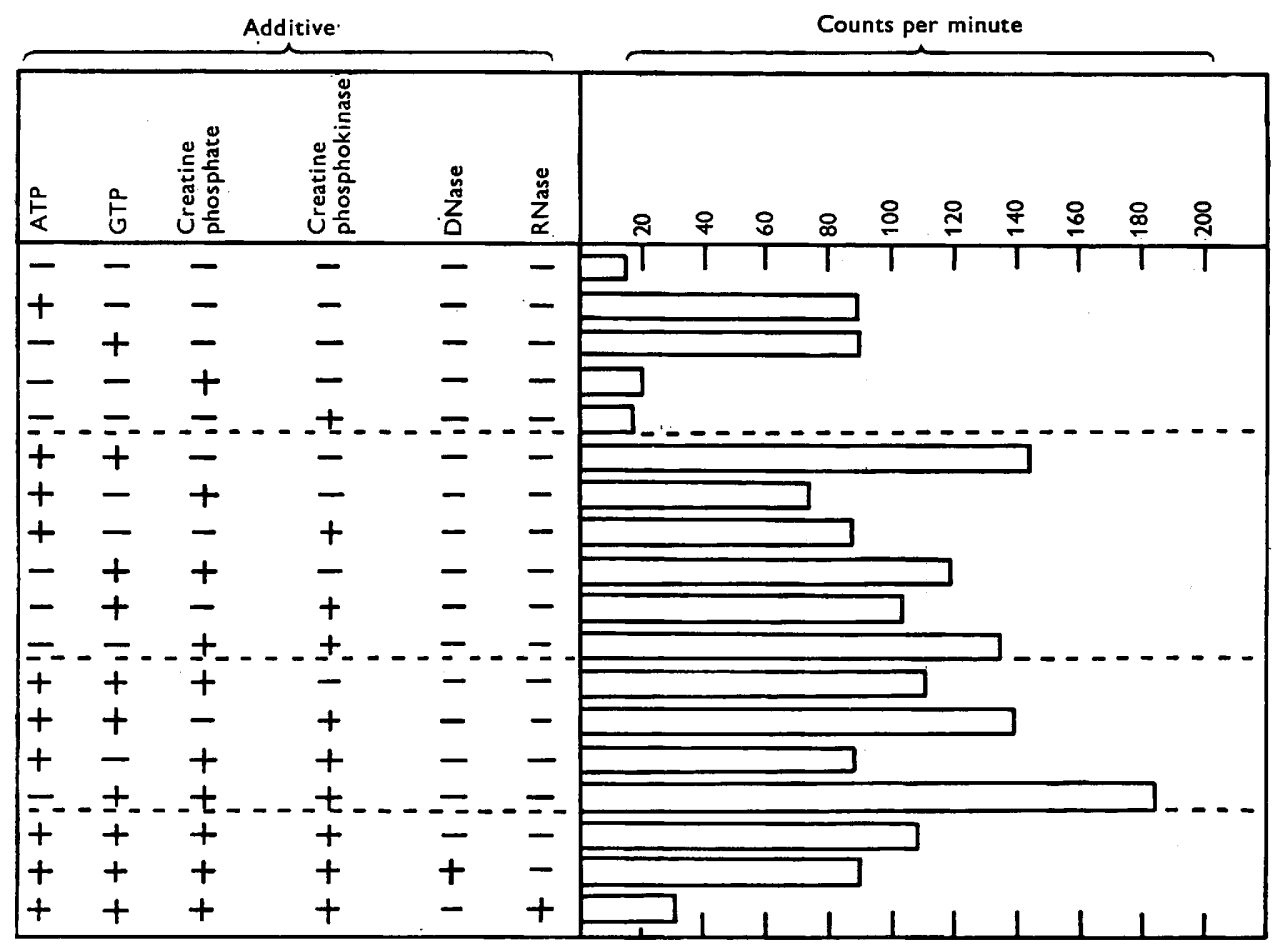

Fig. 1. The effect of various additives on incorporation of $\mathrm{L}$-valine-1-14 $\mathrm{C}$ into paramecium $10,000 \mathrm{~g}$ supernatant fluid fraction. Experimental conditions: volume, $1.6 \mathrm{ml}$. Label, L-valine-1-14 C, $0.25 \mu \mathrm{c}$ (specific activity, 9.8 $\mu \mathrm{c} / \mu$ mole). ATP, $5 \mu$ moles; GTP, $0.5 \mu$ mole; creatine phosphate, $30 \mu$ moles; creatine phosphokinase, $100 \mu \mathrm{g}$. $10,000 \mathrm{~g}$ supernatant fluid, $900 \mu$ g. protein. Sucrose, $250 \mu$ moles; tris, $50 \mu$ moles; $\mathrm{KCl}, 25 \mu$ moles; $\mathbf{M g C l}_{2}$, $5 \mu$ moles. DNase, $10 \mu \mathrm{g}$.; RNase, $1 \mu \mathrm{g}$., pH 7.6. Incubated $55 \mathrm{~min}$. at $33^{\circ}$. Incubation mixtures were then treated as described in Table 1.

\section{Factors involved in the cessation of incorporation}

The effect of repeated addition of $150,000 \mathrm{~g}$ superantant fluid to the incubation system and the effect of pre-incubation of the system's components was examined. The data reported in Table 2 demonstrate that repeated addition of the supernatant fluid fraction caused no increased incorporation (samples 1-4). Pre-incubation of either the pellet fraction or the soluble fraction, in the presence and in the absence of cofactors, caused a marked decrease in incorporative power but did not destroy it. The same was true when the two fractions were incubated together before the introduction of co-factors (samples 5 to 7). The final set (no. 8) shows that significant loss of incorporative power occurred in the system when it was held at $0^{\circ}$. 
A. H. REISNER AND H. MACINDOE

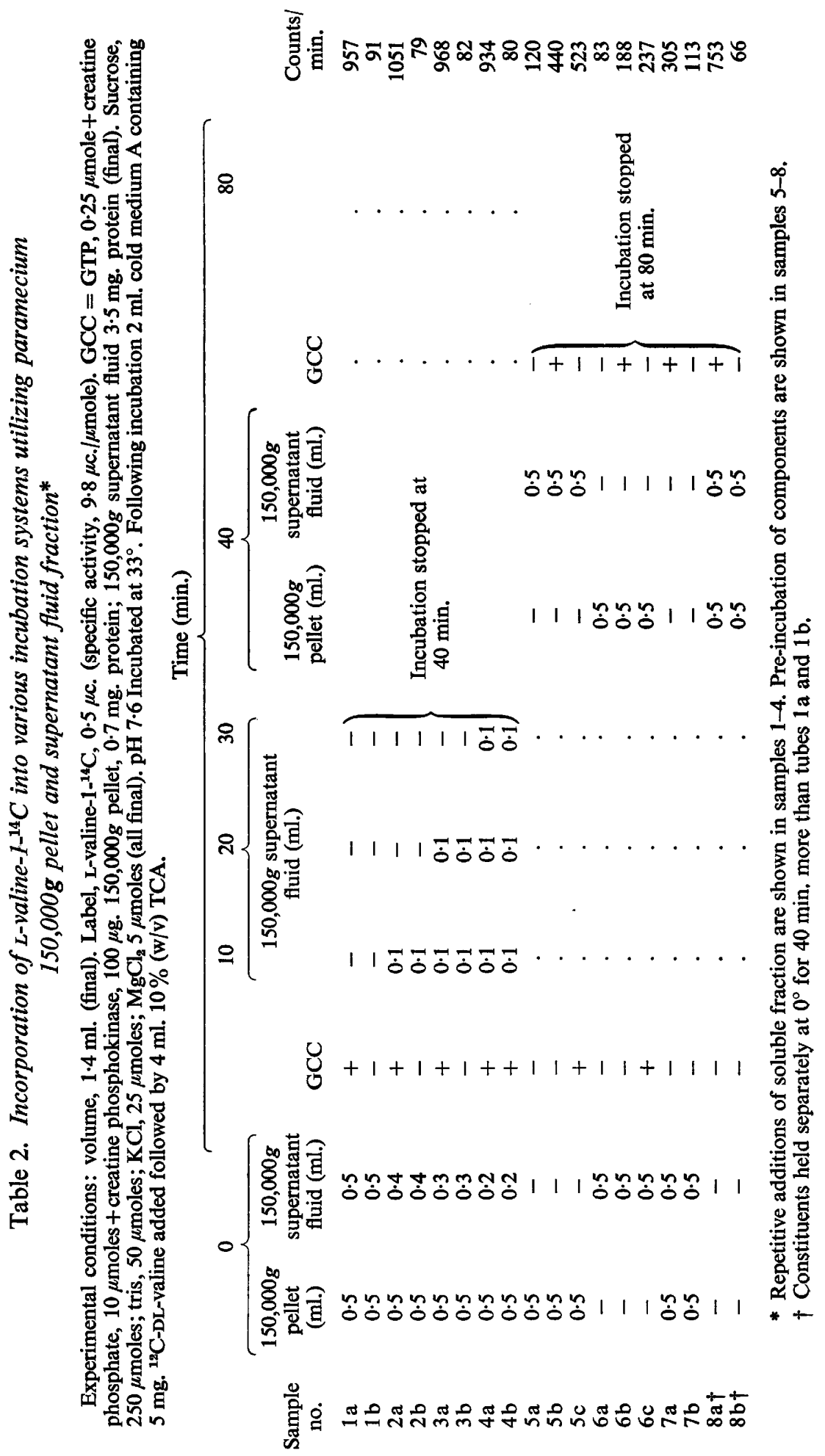




\section{Distribution of ${ }^{14} C$-activity in the constituents of the $10,000 \mathrm{~g}$ supernatant fluid}

The distribution within the $10,000 \mathrm{~g}$ supernatant fluid of incorporated ${ }^{14} \mathrm{C}$-amino acid with respect to soluble and particulate components is given in Table 3 . The total radioactivity of the untreated $150,000 \mathrm{~g}$ pellet was $1170 \mathrm{~d} . \mathrm{p.m}$. (line 3 and line 4) vs. 260 d.p.m. (lines 7 and 8 ) in the $150,000 \mathrm{~g}$ supernatant fluid $\left[\left(\mathrm{NH}_{4}\right)_{2} \mathrm{SO}_{4}\right.$ precipitable, non-dialysable], i.e. less than $20 \%$ of the activity appeared in the soluble protein. The picture was virtually identical in the material taken for pronase treatment-1330 d.p.m. (lines 5 and 6) vs. 338 d.p.m. (lines 9 and 10). Following the $37^{\circ}$ incubation a considerable proportion of the activity in the $150,000 \mathrm{~g}$ pellet and supernatant fluid not subject to pronase treatment was soluble in cold TCA. That this may have been due to endogeneous proteolytic activity is indicated by the fact that the sum of the activities of the $150,000 \mathrm{~g}$ pellet and the soluble fraction $\left(\frac{1}{2} \Sigma\right.$ lines $\left.3-10\right)$ was $102 \%$ that of the whole $10,000 \mathrm{~g}$ supernatant fluid (TCA-insoluble and worked up for counting immediately after incorporation) and the fact that the label was present after dialysis. The addition of pronase to the fractions caused an $88 \%$ decrease of activity in the TCA precipitate of the $150,000 \mathrm{~g}$ pellet and an $80 \%$ decrease in the radioactivity of TCA precipitate of the $150,000 \mathrm{~g}$ supernatant fluid.

Table 3. The effect of pronase on the distribution of ${ }^{14} \mathrm{C}$ activity in the $150,000 \mathrm{~g}$ pellet and $150,000 \mathrm{~g}$ supernatant fluid obtained from a paramecium $10,000 \mathrm{~g}$ supernatant fluid fraction incubated with L-alanine- $1-{ }^{14} \mathrm{C}$

Experimental conditions: nine $1.4 \mathrm{ml}$. incubation mixtures $(7.0 \mathrm{mg}$. protein/tube) set up as described in Table 2 eight with GCC (GTP, $0.25 \mu$ mole + creatine phosphate, $10 \mu$ moles +

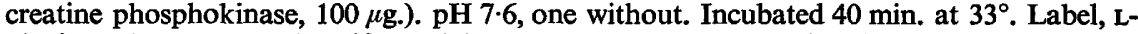
alanine-11-14 $\mathrm{C}, 0.5 \mu \mathrm{c}$. (specific activity, $7.5 \mu \mathrm{c} . / \mu \mathrm{mole}$ ). Following incubation two tubes (one + GCC, one - GCC) were brought to $5 \%$ (w/v) TCA and then prepared for counting. The contents of the remaining seven tubes were pooled and handled as described in Methods. All counts are corrected, using internal standards, to $100 \%$ efficiency.

Sample

Whole $10,000 g$ supernatant fluid

Untreated $150,000 \mathrm{~g}$ pellet

Pronase-treated $150,000 \mathrm{~g}$ pellet

Untreated $150,000 \mathrm{~g}$ supernatant fluid

Pronase-treated 150,000g supernatant fluid

+GCC
-GCC
TCA-precipitate
TCA-supernatant fluid
TCA-precipitate
TCA-supernatant fluid
TCA-precipitate
TCA-supernatant fluid
TCA-precipitate
TCA-supernatant fluid

$$
\begin{gathered}
\text { D.p.m. } / 10 \mathrm{mg} . \\
10,000 \mathrm{~g} \\
\text { supernatant } \\
\text { protein }
\end{gathered}
$$

1520

230

580

590

70

1260

40

220

8

330

\section{Interaction of paramecium and mouse liver fractions}

The data in Table 4 show that both the $150,000 \mathrm{~g}$ supernatant fluid and the ' $\mathrm{pH} 5$ fraction' from mouse liver were able to act in conjunction with paramecium $150,000 \mathrm{~g}$ pellet to give amino acid incorporation. Also, the paramecium soluble fraction stimulated incorporation by twice-washed microsomes (the sum of the separate fractions was 
40 C.P.M. vs. 149 C.P.M. for the combined system) but inhibited incorporation by unwashed mouse microsomes.

\section{Action of inhibitors on amino acid incorporation}

The effect of streptomycin, chloramphenicol and puromycin on amino acid incorporation by paramecium $10,000 \mathrm{~g}$ supernatant fluid is given in Table 5 . Chloramphenicol and streptomycin had little effect on incorporation, in agreement with previous findings with non-bacterial systems (Rendi \& Ochoa,.1962; So \& Davie, 1963; Marcus \& Feeley, 1965), while puromycin down to a concentration of 0.001 $\mu \mathrm{mole} / \mathrm{ml}$. caused significant inhibition.

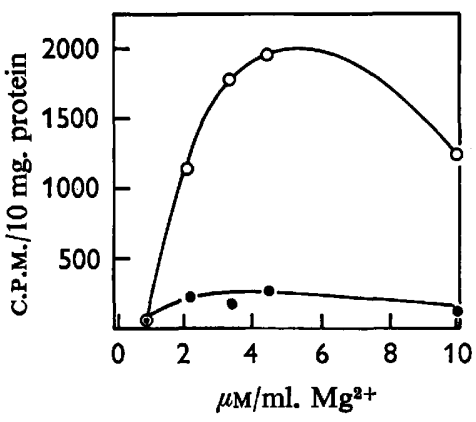

Fig. 2

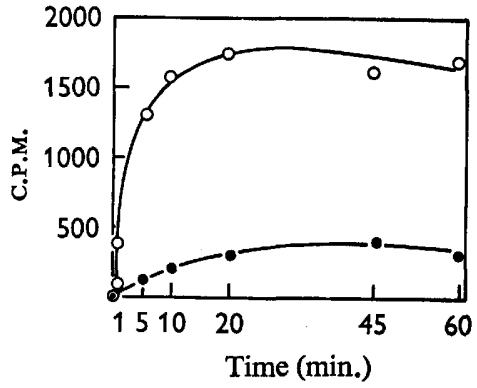

Fig. 3

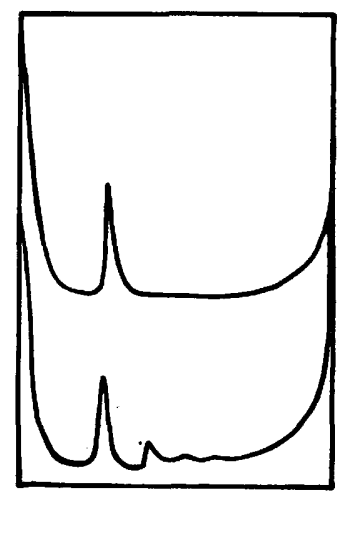

Fig. 4

Fig. 2. The effect of $\mathrm{Mg}^{2+}$ on $\mathrm{L}$-leucine-1-14 $\mathrm{C}$ incorporation into paramecium $10,000 \mathrm{~g}$ supernatant fluid fraction. With GCC, $\mathrm{O}-\mathrm{O}$; Without GCC, - - Experimental conditions: aliquots of packed cells were suspended in five medium A's differing in $\left[\mathrm{Mg}^{2+}\right]$. From each suspension a $10,000 \mathrm{~g}$ supernatant fluid was obtained and its $\left[\mathrm{Mg}^{2+}\right]$ determined. Incubation volume $1.4 \mathrm{ml}$. Label, L-leucine-1-14 $\mathrm{C}, 0.25 \mu \mathrm{c}$ (specific activity, $7 \cdot 1 \mu \mathrm{c} / \mu \mathrm{mole}$ ). GCC $=$ GTP, $0.25 \mu$ mole +creatine phosphate, $10 \mu$ moles +creatine phosphokinase, $100 \mu \mathrm{g}$. Sucrose, $250 \mu$ moles; tris, $50 \mu$ moles; $\mathrm{KCl} 25 \mu$ moles, $\mathrm{pH} \mathrm{7.6}$. Incubated at $33^{\circ}$ for $30 \mathrm{~min}$. Following incubation mixtures were treated as described in Table 1 except that ${ }^{12} \mathrm{C}$-DL-leucine replaced valine.

Fig. 3. Time-course study of $\mathrm{L}$-valine-1 ${ }^{14} \mathrm{C}$ incorporation into paramecium $10,000 \mathrm{~g}$ supernatant fluid fraction. With $\mathrm{GCC}, \mathrm{O}-\mathrm{O}$; Without $\mathrm{GCC}$, - Experimental conditions: volume, $1.4 \mathrm{ml}$. Label $\mathrm{L}$-valine-1-14 $\mathrm{C}, 0.5 \mu \mathrm{c}$. (specific activity, $9.8 \mu \mathrm{c} . / \mu \mathrm{mole}$ ). $\mathrm{GCC}=\mathrm{GTP}, 0 \cdot 25 \mu \mathrm{mole}+$ creatine phosphate, $10 \mu$ mole + creatine phosphokinase, $100 \mu \mathrm{g}$. $10,000 \mathrm{~g}$ supernatant fluid, $5 \cdot 2 \mathrm{mg}$. protein. Sucrose, $250 \mu$ moles; tris, $50 \mu$ moles; $\mathrm{KCl}, 25$ $\mu$ moles, $\mathrm{MgCl}_{2}, 5 \mu$ moles, $\mathrm{pH} \mathrm{7 \cdot 6}$. Incubated $33^{\circ}$. Following incubation the mixtures were treated as described in Table 1.

Fig. 4. Analytical ultracentrifugation of paramecium $10,000 \mathrm{~g}$ supernatant fluid fraction. Speed, $31,410 \mathrm{rev} . / \mathrm{min}$.; diaphragm angle, $55^{\circ}$; temperature, $2 \cdot 7^{\circ}$; solvent, medium A. Top: $1.0 \mu \mathrm{g} . / \mathrm{ml}$. RNase added. Bottom: control. Photo taken $21 \mathrm{~min}$. after reaching speed and $57 \mathrm{~min}$. after adding enzyme. Sedimentation is from left to right. Major peak $=80 \mathrm{~s}$.

\section{Demonstration of polyribosomes in paramecium}

Routine examination in the analytical ultracentrifuge of paramecium $10,000 \mathrm{~g}$ supernatant fluids showed the presence of a relatively large 80 s boundary. In addition, smaller boundaries representing ribosomal dimers, trimers and tetramers could be distinguished and occasionally the pentamers were resolved. To determine whether or 
not the aggregates were polyribosomes, a portion of a $10,000 \mathrm{~g}$ supernatant fluid was mixed with RNase (concentrations of the enzyme were 0.5 and $1.0 \mu \mathrm{g} . / \mathrm{ml}$.) and the mixtures held below $2 \cdot 7^{\circ}$ throughout the experiment. Figure 4 shows that the RNase treatment eliminated the faster-sedimenting boundaries and that the area beneath the 80 s boundary increased. The only difference noted between the $0.5 \mu \mathrm{g} . / \mathrm{ml}$. RNase

\section{Table 4. Interaction of paramecium and mouse liver components in incorporation of L-leucine-1 $1{ }^{14} \mathrm{C}$}

Experimental conditions: volume, $1.5 \mathrm{ml}$. Label, L-leucine-1 ${ }^{-14} \mathrm{C}, 0.25 \mu \mathrm{c}$. (specific activity, $10 \mu \mathrm{c} . / \mu$ mole $). \quad$ AGCC $=$ ATP, $2.5 \mu$ moles + GTP, $0.25 \mu$ mole + creatine phosphate, 10 $\mu$ moles + creatine phosphokinase, $100 \mu \mathrm{g}$. Protein $=$ paramecium $150,000 \mathrm{~g}$ pellet, $1.2 \mathrm{mg}$.; paramecium $150,000 \mathrm{~g}$ supernatant fluid, $2.5 \mathrm{mg}$; mouse unwashed $150,000 \mathrm{~g}$ pellet, $4 \cdot 1 \mathrm{mg}$.; mouse twice washed $150,000 \mathrm{~g}$ pellet, $2.5 \mathrm{mg}$; mouse $150,000 \mathrm{~g}$ supernatant fluid, $26.5 \mathrm{mg}$; mouse 'pH 5 fraction', $0.7 \mathrm{mg}$. Sucrose, $250 \mu$ moles; tris, $50 \mu$ moles; $\mathrm{KCl}, 25 \mu$ moles; $\mathrm{MgCl}_{2}, 5 \mu$ moles. $\mathrm{pH} \mathrm{7.6}$. Incubated $45 \mathrm{~min}$. at $33^{\circ}$. Incubation stopped with the addition of $2 \mathrm{ml}$. medium A containing $5 \mathrm{mg} .{ }^{12} \mathrm{C}-\mathrm{DL}-$ leucine followed by $5 \mathrm{ml} .7 \%(\mathrm{w} / \mathrm{v}) \mathrm{TCA}$.

\begin{tabular}{|c|c|c|c|c|c|c|}
\hline \multirow{2}{*}{$\begin{array}{c}\text { Para- } \\
\text { mecium } \\
150,000 g \\
\text { pellet }\end{array}$} & \multirow{2}{*}{$\begin{array}{l}\text { Para- } \\
\text { mecium } \\
150,000 \mathrm{~g} \\
\text { supernatant } \\
\text { fluid }\end{array}$} & \multirow{2}{*}{$\begin{array}{l}\text { Mouse-liver } \\
150,000 \mathrm{~g} \\
\text { pellet }\end{array}$} & \multirow{2}{*}{$\begin{array}{l}\text { Mouse-liver } \\
150,000 g \\
\text { supernatant } \\
\text { fluid }\end{array}$} & \multirow{2}{*}{$\begin{array}{l}\text { Mouse-liver } \\
\text { 'pH 5' } \\
\text { fraction }\end{array}$} & \multicolumn{2}{|c|}{ Counts per min. } \\
\hline & & & & & $+\mathrm{AGCC}$ & $-\mathrm{AGCC}$ \\
\hline+ & - & - & -- & - & 29. & 12 \\
\hline - & + & - & - & - & 20 & 18 \\
\hline - & - & (Unwashed) & - & - & 650 & 34 \\
\hline - & - & (Twice washed) & - & - & 20 & 17 \\
\hline - & - & - & + & - & 25 & 15 \\
\hline - & - & - & - & + & 49 & 36 \\
\hline+ & + & - & - & - & 111 & 19 \\
\hline+ & - & - & + & - & 137 & 21 \\
\hline+ & - & - & - & + & 444 & 31 \\
\hline- & + & (Unwashed) & - & - & 213 & 32 \\
\hline - & + & (Twice washed) & - & - & 149 & 23 \\
\hline - & - & (Unwashed) & + & - & 1245 & 23 \\
\hline - & - & (Unwashed) & - & + & 1702 & 35 \\
\hline
\end{tabular}

Table 5. The effect of inhibitors on incorporation of L-alanine- $1-^{14} \mathrm{C}$ by paramecium $10,000 \mathrm{~g}$ supernatant fuid fraction

Experimental conditions: volume, $1.5 \mathrm{ml}$. Label, L-alanine-1 $1{ }^{14} \mathrm{C}, 0.25 \mu \mathrm{c}$. (specific activity $12.3 \mu \mathrm{c} . / \mu \mathrm{mole}) . \mathrm{GCC}=\mathrm{GTP}, 0.25 \mu \mathrm{mole}+$ creatine phosphate, $10 \mu$ moles + creatine phosphokinase, $100 \mu \mathrm{g}$. $10,000 \mathrm{~g}$ supernatant fluid, $8.3 \mathrm{mg}$. protein. Sucrose, $250 \mu \mathrm{moles}$; tris, $50 \mu$ moles; $\mathrm{KCl}, 25 \mu$ moles; $\mathrm{MgCl}_{2}, 5 \mu$ moles $\mathrm{pH} 7 \cdot 6$. Incubated $35 \mathrm{~min}$. at $32^{\circ}$; reaction stopped by adding of $1.5 \mathrm{ml} .10 \%$ (w/v) TCA.

$\begin{array}{lcc}\text { Inhibitor }(\mu \text { mole/ml.) } & \begin{array}{c}\text { Counts } \\ \text { per min. }\end{array} & \begin{array}{c}\% \\ \text { inhibition }\end{array} \\ \text { None } & 388 & 0 \\ \text { - GCC } & 70 & 82 \\ \text { Streptomycin 0.1 } & 322 & 17 \\ \text { Streptomycin 0.01 } & 404 & -4 \\ \text { Chloramphenicol 0.1 } & 353 & 9 \\ \text { Chloramphenicol 0.01 } & 332 & 14 \\ \text { Puromycin 0.1 } & 97 & 75 \\ \text { Puromycin 0.01 } & 203 & 48 \\ \text { Puromycin 0.001 } & 243 & 37\end{array}$


treatment and the $1.0 \mu \mathrm{g} . / \mathrm{ml}$. treatment was that in the former a small amount of dimer was still present in the early stages of the run.

\section{Incorporation of amino acid into gradient fractions of paramecium $10,000 \mathrm{~g}$ superantant fluid}

To determine whether ribosomal activity could be directly shown in paramecia, the experiments described in Fig. 5 were made. The data from the 60 min. centrifugation (Fig. $5 a$ ) indicate a measure of activity in the lower fractions of the gradient. Similar

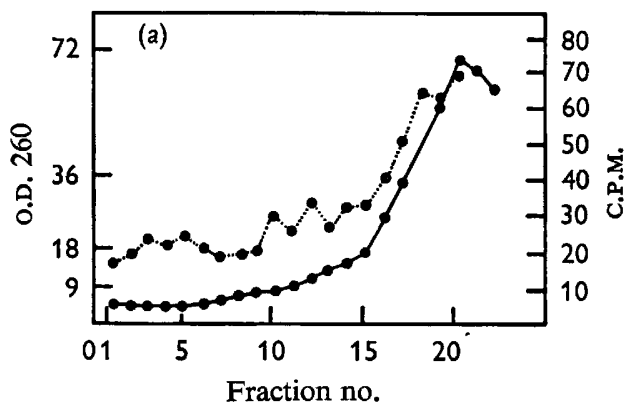

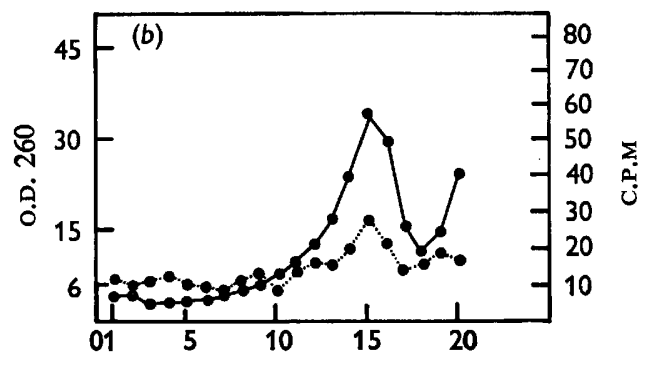

Fraction no.

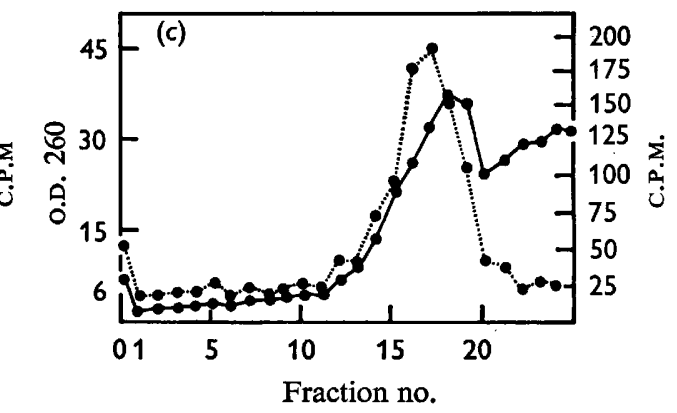

Fig. 5. Distribution of incorporation activity in sucrose density gradient centrifugations of paramecium 10,000 g supernatant fluid fraction. Counts per minutes (C.P.M.), 0.... ; optical density (o.D.) at $260 \mathrm{~m} \mu$, - $\longrightarrow$. Experimental conditions: $15-30 \%$ linear sucrose gradients made up in medium A were overlayered with paramecium $10,000 \mathrm{~g}$ supernatant fluid and centrifuged in the Spinco SW 25-1 rotor at $53,000 \mathrm{~g}$ for $60 \mathrm{~min}$. $(5 a), 120 \mathrm{~min}$. $(5 b)$ or $90 \mathrm{~min}$. (5c). $1 \mathrm{ml}$. samples were removed through the bottom of the tubes for incubation. Incubation: volume, $1.5 \mathrm{ml}$. Label, $(a, b)$ L-leucine-1-14 $\mathrm{C}, 0.25 \mu \mathrm{c}$. (specific activity $10 \mu \mathrm{c}$. $/ \mathrm{mole}$ ); (c) L-alanine-1-14 $\mathrm{C}, 0.5 \mu \mathrm{c}$. (specific activity, $7.5 \mu \mathrm{c}$. $/ \mathrm{mole}$ ). ATP, $2.5 \mu$ moles; GTP, $0.25 \mu$ mole; creatine phosphate, $10 \mu$ moles; creatine phosphokinase, $100 \mu$ g. tris, $50 \mu$ moles; $\mathrm{KCl}, 25 \mu$ moles; $\mathrm{MgCl}_{2}, 10 \mu$ moles; Sucrose $490 \mu$ to $75 \mu$ moles. Paramecium 150,000g supernatant fluid, $1 \cdot 1 \mathrm{mg}$. protein $(a, b)$. Mouse liver ' $\mathrm{pH} 5$ fraction', $0.27 \mathrm{mg}$. protein $(c), \mathrm{pH} 7 \cdot 6$. Incubated $45 \mathrm{~min}$. at $33^{\circ}$. Following incubation $2 \mathrm{ml}$. cold medium A added containing $5 \mathrm{mg}$. bovine $\gamma$ globulin and $5 \mathrm{mg}$. ${ }^{12} \mathrm{C}$-DL-leucine $(a, b)$ or ${ }^{12} \mathrm{C}$-DL-alanine $(c)$ followed by $5 \mathrm{ml} .7 \%(\mathrm{w} / \mathrm{v})$ TCA.

observations were made on a $30 \mathrm{~min}$. centrifugation. In the $120 \mathrm{~min}$. centrifugation (Fig. $5 b$ ) the 80 s ribosomes had moved well away from the top of the gradient and there was a correlation of amino acid incorporation with them. The use of mouse liver ' $\mathrm{pH} 5$ fraction' also caused incorporation which appeared with the 80s peak (Fig. 5 c). 


\section{The effect of $\mathrm{Mg}^{2+}$ on the distribution of ${ }^{14} \mathrm{C}$-amino acid associated with the 80 s ribosomes}

Amino-acid-labelled 80 s ribosomes from paramecia were prepared as described under Methods. The results appear in Fig. 6. Comparable material was also examined in an analytical ultracentrifuge. Figure $6 a\left(10^{-2} \mathrm{M}-\mathrm{Mg}^{2+}\right)$ shows excellent correlation
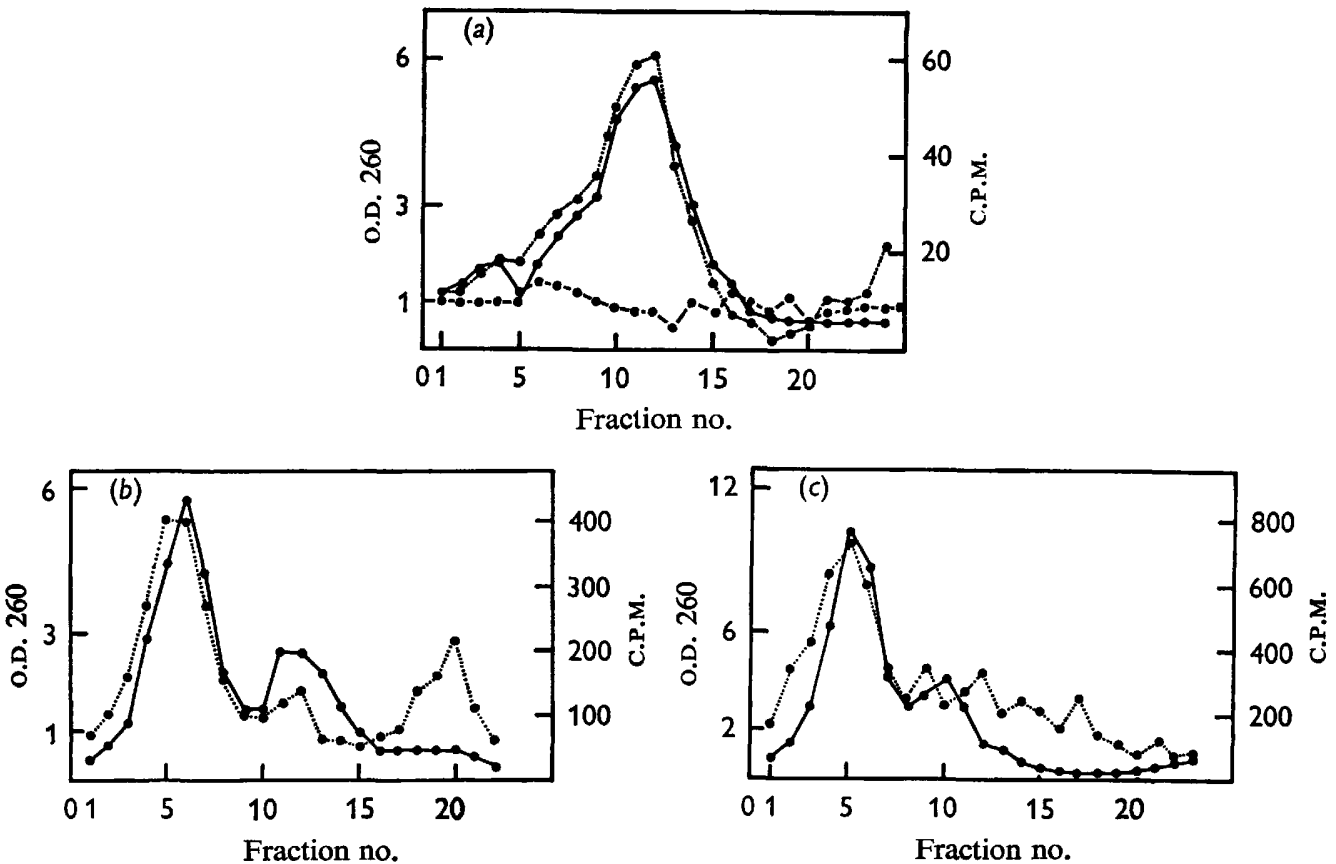

Fig. 6. Effect of $\left[\mathrm{Mg}^{2+}\right]$ and dialysis time on the distribution of 80 s ribosomal material and associated amino acid in sucrose density gradients. C.P.M., -.... C C.P.M. (without AGCC), - . - O.D. $260 \mathrm{~m} \mu$,

Experimental conditions:

(a) Incubation-volume, $27 \mathrm{ml}$. Label, $9 \mu \mathrm{c}$. L-alanine-1-14 $\mathrm{C}$ (specific activity $7.5 \mu \mathrm{c}$ /) $\mu$ mole). AGCC $=$ ATP, $45 \mu$ moles + GTP, $4 \cdot 5 \mu$ moles + creatine phosphate, $180 \mu$ moles + creatine phosphokinase, $1.8 \mathrm{mg}$. Paramecium $150,000 \mathrm{~g}$ pellet, $30 \mathrm{mg}$. protein; mouse liver 'pH 5 fraction', 26 mg. protein. Tris, $900 \mu$ moles; $\mathrm{KCl}, 450 \mu$ moles; $\mathrm{MgCl}_{2}, 90 \mu$ moles $\mathrm{pH} 7.6$. Incubated $45 \mathrm{~min}$. at $33^{\circ}$. After obtaining purified $80 \mathrm{~s}$ ribosomes as described in Methods, they were dialyzed $15 \mathrm{hr}$ against two changes of medium $\mathrm{A}, \mathrm{Mg}^{2+}=10^{-2} \mathrm{M}$, no sucrose. The impermeate was layered on a 5-20\% linear sucrose gradient in medium A $\mathrm{Mg}^{2+}=10^{-2} \mathrm{M}$ and centrifuged two $\mathrm{hr}$ at 53,000 $\mathrm{g}$ in the Spinco SW 25-1 rotor.

(b) Incubation-volume, $8.4 \mathrm{ml}$. Label, $3 \mu \mathrm{c}$. reconstituted protein hydrolysate. GTP, $1.5 \mu$ moles; creatine phosphate, $60 \mu$ moles; creatine phosphokinase $0.6 \mathrm{mg}$. Paramecium $10,000 \mathrm{~g}$ supernatant fluid, $35 \mathrm{mg}$. protein. Sucrose, $1.5 \mu$ moles; tris, $300 \mu$ moles; KCl, $150 \mu$ moles; $\mathrm{MgCl}_{2}, 30 \mu$ moles, $\mathrm{pH} \mathrm{7.6}$. Incubated $30 \mathrm{~min}$. at $33^{\circ}$. After obtaining purified 80 s ribosomes as described in Methods, they were dialysed $15 \mathrm{hr}$ against two changes of medium A containing no sucrose and no $\mathrm{Mg}^{2+}$. The impermeate was layered on a 5 to $20 \%$ sucrose gradient in medium $\mathrm{A}$ (no $\mathrm{Mg}^{2+}$ ) and centrifuged seven hr at 53,000g.

(c) Incubation-volume, $7 \mathrm{ml}$. Label $2.5 \mu \mathrm{c}$. reconstituted protein hydrolyzate. GTP, 1.25 $\mu$ moles; creatine phosphate, $50 \mu$ moles; creatine phosphokinase, $0.5 \mathrm{mg}$. Paramecium $10,000 \mathrm{~g}$ supernatant fluid, $50 \mathrm{mg}$. protein. Sucrose, 1.25 mmoles; tris, $250 \mu$ moles; $\mathrm{KCl} 125$ $\mu$ moles; $\mathrm{MgCl}_{2}, 25 \mu$ moles, $\mathrm{pH} 7 \cdot 6$. Incubated $35 \mathrm{~min}$. at $31^{\circ}$. Following incubation the preparation was handled as $6 b$ except that it was dialysed $4.5 \mathrm{hr}$ against three changes of buffer before layering on the $5-20 \%$ gradient. 
between the absorbency and radioactivity curves. The analytical ultracentrifuge showed that the majority of material was present in the $80 \mathrm{~s}$ form but that a considerable degree of spontaneous polymerization had taken place after overnight dialysis against $10^{-2} \mathrm{M}-\mathrm{Mg}^{2+}$. This was substantiated by the marked shoulder seen between fractions 5 and 9 of Fig. $6 a$. Figure $6 b$ shows the distribution of material from 80 s ribosomes subjected to dialysis for $15 \mathrm{hr}$ against buffer deficient in $\mathrm{Mg}^{2+}$ followed by centrifugation for $7 \mathrm{hr}$, while Fig. $6 c$ shows the distribution obtained when dialysis was for $4.5 \mathrm{hr}$. The analytical ultracentrifuge showed the presence of $45 \mathrm{~s}$ and $30 \mathrm{~s}$ boundaries. While over $95 \%$ of the TCA-insoluble label present in the initial 80 s material was recovered from the gradients shown in Fig. $6 a$ and $6 c$, only two-thirds of that present initially in the experiment shown in Fig. $6 b$ was recovered.

\section{DISCUSSION}

The experiments described indicate that Paramecium aurelia stock 51 was able to incorporate amino acid into protein via the ribosomal route. For incorporation to occur the $150,000 \mathrm{~g}$ supernatant fluid (soluble fraction) was required together with guanosine triphosphate (GTP) and either adenosine triphosphate (ATP) or an ATPgenerating system (Table 1; Fig. 1). Furthermore, the stimulation by GTP and ATP (or the ATP generating system) supplemented one another (Fig. 1), suggesting that these compounds played different roles in incorporation as would be expected from the presently accepted model of protein biosynthesis. While the paramecium system was essentially unaffected by DNase treatment, it showed a marked sensitivity to submicrogram amounts of RNase, indicating a requirement for labile RNA, e.g. messenger RNA. That the protease pronase (Nomoto, Narahashi \& Murakami, 1960) released the label into the cold TCA supernatant fluid and that puromycin inhibited incorporation into the TCA precipitate support the conclusion that the amino acid was incorporated into protein via peptidyl-RNA intermediates (Allen \& Zamecnik, 1962; Zamecnik, 1962).

The time-course of incorporation in Fig. 3 shows a rapid decay in the rate of incorporation similar to that reported by Chesters (1966) for Crithidia oncopelti. That this decay was not alleviated by repeated additions of soluble fraction to the system is shown in Table 2 (samples 1-4). It appears unlikely, therefore, that the paramecium system was capable of much de novo protein synthesis. More probably polypeptides present when incubation began were augmented, and any chain initiation which occurred was not carried to completion of the polypeptide. The relatively small amount of label ( $<20 \%$ ) found in the protein of the soluble fraction after incubation (Table 3, 150,000 g supernatant fluid) is additional support for this conclusion.

That contaminating micro-organisms played no significant part in incorporation is indicated by the following observations: the mass cultures used for these studies were free from bacterial and fungal contaminants; soluble fraction, $150,000 \mathrm{~g}$ pellet and cofactors were all required for incorporation; incorporation ceased after incubation for $10 \mathrm{~min}$.; the ${ }^{14} \mathrm{C}$-label became associated with 80 s ribosomes.

The experiments reported in Table 2 (samples 5-8) show that pre-incubation of the soluble fraction together with the ribosomal fraction caused a two-thirds loss in activity (305 vs. 957 C.P.M.) while a somewhat less severe loss occurred when ribosomes alone were pre-incubated. These findings are substantially in agreement with those of 
Marcus \& Feeley (1965) who worked with a cell-free system from peanut cotyledon and are characteristic of ribosomally-controlled amino acid incorporation systems (Allen \& Schweet, 1962; Matthaei \& Nirenberg, 1961). However, pre-incubation of paramecium soluble fraction alone caused a severe decrease of activity in contrast to Marcus \& Feeley's results. When this observation is considered in conjunction with the finding that paramecium soluble fraction caused marked inhibition of amino acid incorporation by unwashed mouse liver microsomes, while mouse liver ' $\mathrm{pH} 5$ fraction' allowed a fourfold increase in incorporation by paramecium ribosomes (as compared with paramecium soluble fraction, Table 5), we have a clear indication of the presence of inhibitors in the paramecium $150,000 \mathrm{~g}$ supernatant fluid. Furthermore, it appears that during incubation destruction of essential components occurred.

The finding that mouse liver $150,000 \mathrm{~g}$ supernatant fluid and ' $\mathrm{pH} 5$ fraction' (Table 4) stimulated amino acid incorporation by paramecium ribosomes and that paramecium soluble fraction stimulated incorporation by washed mouse microsomes, is a direct indication that the paramecium system follows the classical model. However, not until specific proteins are isolated from these hybrid systems will it be possible to determine whether mouse messenger RNA combines with free paramecium ribosomes to make mouse protein, or whether mouse transfer RNA supplies amino acids to paramecium messenger RNA.

Evidence which implicates the paramecium ribosomes in incorporation comes from the sucrose density gradient experiments (Figs. 5,6$)$. Figure $5(b, c)$ shows a correlation of radioactivity with the 80s material, while Fig. $5 a$ indicates that some active polyribosomes might have been present in the gradient. The substitution of mouse 'pH 5 fraction' (Fig. 5c) for paramecium soluble fraction caused a distinct shift of the radioactivity peak (relative to $260 \mathrm{~m} \mu$ extinction) toward the lower end of the gradient. This shift may have been due to the presence of inhibitors from the paramecium soluble fraction which contaminated the higher fractions of the gradient, for no such shift is seen in Fig. $6 a$ which utilized paramecium $150,000 \mathrm{~g}$ pellet and mouse ' $\mathrm{pH} 5$ fraction'. Figure $6 a$ shows that a correlation between radioactivity and $260 \mathrm{~m} \mu$ extinction persisted when purified amino acid-labelled 80s ribosomes formed spontaneous polymers at $10^{-2} \mathrm{M}-\mathrm{Mg}^{2+}$. Upon dissociation of the $80 \mathrm{~s}$ particles into $45 \mathrm{~s}$ and 30s subunits (Fig. $6 b, c$ ) little label was associated with the smaller subunit, while the $45 \mathrm{~s}$ unit retained marked radioactivity. While the specific activity of the $45 \mathrm{~s}$ unit was not appreciably affected by prolonged dialysis (Fig. $6 b v s$. $6 c$ ), one-third of TCA precipitable label present in the initial material was lost; and the released protein is seen to peak in fraction 20. In the gradient of the $4.5 \mathrm{hr}$ dialysis essentially all of the TCA precipitable label present initially was recovered and in place of a peak near the top of the gradient there is a trail of radioactivity through the top half of gradient. These observations suggest that a considerable fraction of the nascent protein was tightly bound to the $45 \mathrm{~s}$ unit and was neither degraded nor released by prolonged exposure to low $\mathrm{Mg}^{2+}$ concentrations. However, the nascent protein which was released by low $\mathrm{Mg}^{2+}$ concentrations reflects prolonged exposure in a change of position in the gradient and by a significant loss of material. Possibly these findings indicate that in the experiment shown in Fig. $6 c$ the nascent protein was released from one or the other of the subunits only during centrifugation. If proteolytic activity during extended dialysis was responsible for the loss of label, release of the nascent protein only during the course of centrifugation might have effectively protected against such 
activity. Alternatively there might have been a degree of disintegration associated with ribosomal dissociation. Initially the released protein might have been bound to ribosomal fragments from which it later dissociated. Peptides too small to have been retained during dialysis or precipitated by TCA would have been lost.

Tashiro \& Siekevitz (1965), who used guinea-pig hepatic ribosomes pulse-labelled in vivo with amino acid and dissociated with a chelator, reported results virtually identical with the pattern shown in Fig. 6b, while Philipps (1966) with rabbit reticulocyte ribosomes presented evidence indicating that upon ribosomal dissociation the nascent protein might be bound to either subunit. In this connexion it is interesting to note that the reticulocyte ribosomes dissociated to give compact 60 s and 40 s subunits, while paramecium ribosomes dissociate into the more open $45 \mathrm{~s}$ and $30 \mathrm{~s}$ forms (A. H. Reisner \& H. Macindoe, unpublished results). In the latter system the secondary bonds which tend to bind the polypeptide to both of the subunits may become disrupted allowing the peptidyl-RNA-ribosomal bond to play a more dominant role.

Concerning the sensitivity of the protein synthetic mechanism in paramecium to $\left[\mathrm{Mg}^{2+}\right]$ (Fig. 2) a similar optimum and narrowness of range is noted by Chesters (1966) in the only other protozoan examined. It is noteworthy that at concentrations below $3 \mu \mathrm{moles} / \mathrm{ml}$. $\mathrm{Mg}^{2+}$, where incorporation shows a very sharp decline, examination of ribosomal structure in paramecium (A. H. Reisner \& H. Macindoe, unpublished results) reveals that the $80 \mathrm{~s}$ ribosomes $\left(\mathrm{S}_{\mathrm{O}_{20 \mathrm{w}}}=84.5 \mathrm{~s}\right)$ undergo marked hydration. Thus at $1 \mu \mathrm{mole} / \mathrm{ml}$. $\mathrm{Mg}^{2+}$ about $75 \%$ of the ribosomes are in a hydrated 60 s form (no $45 \mathrm{~s}$ or $30 \mathrm{~s}$ material is detectable). Polyribosomes are still present at this $\mathbf{M g}^{2+}$ concentration but have reduced sedimentation coefficients. The reduction of amino acid incorporation into protein within the range of 1 to $4 \mu \mathrm{moles} / \mathrm{ml} . \mathrm{Mg}^{2+}$ may be, therefore, a direct consequence of ribosomal disorganization.

We are indebted to Dr W. J. van Wagtendonk for a single-membered culture of paramecia, for testing our early baker's yeast preparations and for suggestions in developing the new culture medium. Our thanks are due to Dr J. K. Chesters for permission to refer to his manuscript prior to publication and to Misses R. Price and D. Bramfitt for able technical assistance.

\section{REFERENCES}

Allen, E. H. \& Schweet, R. S. (1962). Synthesis of hemoglobin in a cell-free system I. Properties of the complete System. J. biol. Chem. 237, 760 .

AlleN, D. W. \& ZAMECNIK, P. C. (1962). The effect of puromycin on rabbit reticulocyte ribosomes. Biochim. biophys. Acta 55, 865.

Camprell, P. N. (1965). The biosynthesis of proteins. Progress in Biophysics and Molecular Biology $15,3$.

CHEsters, J. K. (1966). Protein synthesis by cell-free extracts of Crithidia oncopelti. Biochim. biophys. Acta 114, 385.

Fruton, J. S. (1963). Chemical aspects of protein synthesis. In The Proteins, second edition, ed. by H. Neurath, vol. I, p. 189. New York: Academic Press.

Lowry, O. H., Rosebrough, N. J., FARr, A. L. \& Randall, R. J. (1951). Protein measurement with the folin phenol reagent. J. biol. Chem. 193, 265.

MACINDOE, H. \& ReISNER, A. H. (1967). Adsorption titration as a specific semi-quantitative assay for soluble and bound paramecium serotypic antigen. Aust. J. Biol. Sci. (in the Press).

MAGER, J. (1960). Chloramphenicol and chlortetracycline in inhibition of amino acid incorporation into proteins in a cell-free system from Tetrahymena pyriformis. Biochim. biophys. Acta 38, 150.

MAGER, J. \& LIPMANN, F. (1958). Amino acid incorporation and the reversion of its initial phase with cell-free Tetrahymena preparations. Proc. natn. Acad. Sci. U.S.A. 44, 305. 
Marcus, A. \& Feeley, J. (1965). Protein synthesis in imbibed seeds. II. Polysome formation during imbibition. J. biol. Chem. 240, 1675.

MAtThaeI, J. H. \& NirenberG, M. W. (1961). Characters and stabilization of DNAse-sensitive protein synthesis in Escherichia coli extracts. Proc. natn. Acad. Sci. U.S.A. 47, 1580.

Nomoto, M., Narahashi, Y. \& MURAKami, M. (1960). The proteolytic enzyme of Streptomyces griseus. Part 7: Substrate specificity of $S$. griseus and protease. J. Biochem. 48, 906.

Orange, M. \& Rhein, H. C. (1951). Microestimation of magnesium in body fluids, J. biol. Chem. $189,379$.

PHILIPPs, G. R. (1966). Protein synthesis on reticulocyte ribosomes. II. The binding of peptidyl-sRNA to ribosomes. J. mol. Biol. $15,587$.

RENDI, R. \& OCHOA, S. (1962). Effect of chloramphenicol on protein synthesis in cell-free preparations of Escherichia coli. J. biol. Chem. 237, 3711.

Seaman, G. R. (1962). Protein synthesis by kinetosomes isolated from the protozoan Tetrahymena. Biochim. biophys. Acta 55, 889.

So, A. G. \& DAVIE, W. E. (1963). The incorporation of amino acids into protein in a cell-free system from yeast. Biochemistry 2, 132.

TASHIRO, Y. \& SIEKEVITZ, P. (1965). Localization on hepatic ribosomes of protein newly synthesized in vivo. J. mol. biol. 11, 166.

ZAMECNIK, P. C. (1962). Unsettled question in the field of protein synthesis. Biochem. J. 85, 257. 